ORIGINAL PAPER

https://doi.org/10.17059/ekon.reg.2020-4-24

UDC 334 (cc) BY 4.0

Purwanto $^{a)}$, Ina Primiana ${ }^{\text {b) }}$, Dian Masyita ${ }^{c)}$, Erie Febrian d)

a) President University, Bekasi, Indonesia

b, c, d) Padjadjaran University, Bandung, Indonesia

a) e-mail: purwanto@president.ac.id

\title{
Alleviating Poverty through Islamic Microfinance: Outreach and Efficiency (Study on BMT and Islamic Cooperatives in Indonesia)
}

The involvement of Islamic Microfinance Institutions (IMFI) in building the national economy is paramount to help the poor. However, provision of access and services to lower-level households can potentially conflict with the sustainability of the institutions. This study analyses the social outreach factors that determine financial and social efficiencies. To reach the set goal and solve this issue, we used mixed methodology combining quantitative (statistical instruments, such as Data Envelopment Analysis (DEA) and multivariate analysis) and qualitative approaches (interviews to clarify or deepen the existing information). The assessment of the dependent variables is influenced by proxies of depth, breadth, length, scope, and cost. The results showed that the average loan instalments and the number of offices and branches significantly influence financial and social efficiency. The age of the institution only has an effect on financial efficiency. Simultaneously, profit orientation, the amount and type of financing and the amount and type of savings only have a high impact on social efficiency, whereas the impact of fund collection and cost per borrower is insignificant. There is a strong positive correlation between the two dependent variables. The influence of independent variables on financial and social efficiency is significant with the coefficient of determination $23.1274 \%$ and $53.2941 \%$, respectively.

Keywords: cost, economic efficiency, social efficiency, average loan instalment, number of offices, age, profit orientation, fund collection, amount and type of financing, amount and type of savings, cost per borrower, Islamic Microfinance Institution

\section{Acknowledgement}

We extend our gratitude to the West Java Board of Trustees and the BMT Cooperatives, the supervisors, reviewers, and all parties who assisted in this research.

For citation: Purwanto, Primiana, I., Masyita, D. \& Febrian, E. (2020). Alleviating Poverty through Islamic Microfinance: Outreach and Efficiency (Study on BMT and Islamic Cooperatives in Indonesia). Ekonomika regiona [Economy of region], 16(4), 1362-1376, https://doi.org/10.17059/ekon.reg.2020-4-24

\footnotetext{
1 (c) Purwanto, Primiana I., Masyita D., Febrian E.
} 


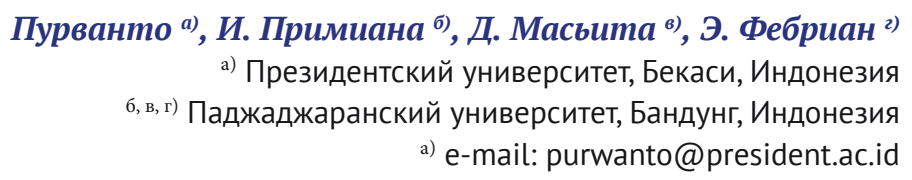

\title{
Охват и эффективность исламского микрофинансирования в борьбе с бедностью (ВМТ и исламские кооперативы в Индонезии)
}

\begin{abstract}
Исламские микрофинансовые организации играют важную роль в укреплении национальной экономики Индонезии, поскольку они оказывают значительную помощь малоимущим. Однако предоставление доступа и услуг низшему классу может негативно сказаться на устойчивости данных организаций. В этом исследовании проанализированы факторы социального охвата, определяющие финансовую и социальную эффективность помощи. Для решения поставленной проблемы была использована смешанная методология, сочетающая количественный (статистические инструменты: анализ охвата данных и многофакторный анализ) и качественный подходы (интервью для уточнения полученной информации). На оценку зависимых переменных влияют значения опосредованных переменных глубины, иирины, продолжительности, объема и стоимости. Результаты показали, что средний взнос по кредиту и количество обисов и филиалов организаций оказывают существенное влияние как на финансовую, так и на соииальную эфбективность. Возраст учреждения влияет только на финансовую эффективность. Такие факторы, как ориентация на прибыль, размер и тип финансирования, а также число и тип накоплений имеют сильное влияние только на социальную эфбективность, в то время как влияние переменных «объем фондов» и «затраты на заемшика» незначительно. Между двумя зависимыми переменными существует сильная положительная корреляция. Влияние независимых переменных на финансовую и социальную эффективность значимо, исходя из значений коэффициента детерминации $23,1274 \%$ u $53,2941 \%$.

Ключевые слова: стоимость, экономическая эффективность, социальная эффективность, средний взнос по кредиту, количество офисов, возраст, ориентация на прибыль, объем фондов, размер и тип финансирования, число и тип накоплений, затраты на заемщика, Исламские микрофинансовые организации
\end{abstract}

\section{Благодарность}

Авторы выражают благодарность Попечительскому совету Западной Явы и кооперативам ВМТ, руководителям, рецензентам и всем людям, вовлеченным в исследование.

Для цитирования: Пурванто, Примиана И., Масьита Д, Фебриан Э. Охват и эффективность исламского микрофинансирование в борьбе с бедностью (ВМТ и Исламские кооперативы в Индонезии) // Экономика региона. 2020. Т. 16, вып. 4. С. 1362-1376. https://doi.org/10.17059/ekon.reg.2020-4-24

\section{Introduction}

The involvement of micro-enterprises in building national economic sustainability is paramount; however, this sector is difficult to develop because its activities come from the lower-level communities that are hard to reach. Formal financial institutions claim that actors in this segment do not have the potential for funds, thus hampering their development. Micro, Small, and Medium Enterprises (MSMEs) in Indonesia largely depend on informal financing sources and Microfinance Institutions (MFIs) due to limited access to banking. Microfinance institutions have special characteristics, such as providing credit to micro/small businesses and the poor. Therefore, many practitioners agree that in assessing the performance of a microfinance institution, we must pay attention to its outreach. Compared to the banking sector, there is not much research on the efficiency of Micro Finance Institutions such as Baitul Maal wat Tamwil (BMT) and Islamic Cooperatives (Kopsyah) because operations in the target field should be run concurrently. Financial ratios are not suitable for investigating various sources of inefficiency.

According to [1], transaction costs are very high due to the provision of credit to the poor, especially in terms of screening, monitoring and administrative costs per loan. Islamic Microfinance Institutions (IMFIs) should optimise existing resources and minimise operating costs. Efficiency improvement measures include taking public funds or capital from third parties, but in managing IMFIs it is left to market mechanisms, which tend to lead to the commercialisation of MFIs [2]. A number of research results [1, 3-9] indicate a trade-off between the sustainability of MFIs with their outreach to the poor. On the one hand, some institutions wish to expand the reach of services by attracting large clients and gaining high profits. On the other hand, they are oriented to the depth of service to the poorest people who need subsidies so that their lives could change.

The initial survey related to financial statements was conducted on ten BMT/Kopsyah in the 
Table 1

Preliminary Survey Regarding Financial Statements

\begin{tabular}{|l|c|c|c|c|c|}
\hline \multicolumn{1}{|c|}{ Financial Highlight } & $\mathbf{2 0 1 5}$ & $\mathbf{2 0 1 6}$ & $\mathbf{2 0 1 7}$ & $\mathbf{2 0 1 8}$ & Note \\
\hline Assets (Rupiah) & $472,442,314$ & $552,377,561$ & $609,638,723$ & $647,489,549$ & Increase \\
\hline Deposits (Rupiah) & $349,446,176$ & $419,206,712$ & $472,969,658$ & $498,381,435$ & Increase \\
\hline Funding (Rupiah) & $255,718,692$ & $304,919,138$ & $336,652,964$ & $336,231,054$ & Fluctuate \\
\hline Income (Rupiah) & $70,151,274$ & $74,719,776$ & $89,396,172$ & $85,093,251$ & Fluctuate \\
\hline Profit (Rupiah) & $21,638,858$ & $21,252,410$ & $23,460,013$ & $25,437,488$ & Fluctuate \\
\hline Number of Members (People) & 154.6 & 157.3 & 174.4 & 176.4 & Increase \\
\hline Number of Employees (People) & 8.4 & 8.5 & 8.3 & 8.2 & Fluctuate \\
\hline
\end{tabular}

Source: Processed from financial statements, 2019.

Preliminary Interview Results

\begin{tabular}{|c|l|l|}
\hline No. & \multicolumn{1}{|c|}{ Questions } & \multicolumn{1}{c|}{ Answers } \\
\hline 1. & $\begin{array}{l}\text { Depth of Outreach } \\
\text { How can BMT/Kopsyah provide } \\
\text { benefits, increase revenue, and } \\
\text { create independent customers? }\end{array}$ & $\begin{array}{l}\text { The institution aims to advance the welfare of members, provide loans, and help } \\
\text { people surviving in difficult economic conditions. The portion of small groups is } \\
\text { not large; the activities include murabahah. These have not led to MSMEs, small } \\
\text { traders are constrained by the rate of return while they are at the middle level }\end{array}$ \\
\hline 2. & $\begin{array}{l}\text { Breadth of Outreach } \\
\text { How do BMT/Kopsyah serve } \\
\text { the wider community, increase } \\
\text { increase its assets? }\end{array}$ & $\begin{array}{l}\text { They help by providing excellent service, providing value added investment } \\
\text { through professional management, socialising and introducing Islamic financial } \\
\text { institutions to worshippers through traditional marketing tools (banners) and ex- } \\
\text { panded networks. There are efforts to increase assets through principal/manda- } \\
\text { tory savings and member recruitment }\end{array}$ \\
\hline 3. & $\begin{array}{l}\text { Length of Outreach } \\
\text { How do BMT/Kopsyah serve in } \\
\text { a long and continuous period? }\end{array}$ & $\begin{array}{l}\text { Society, employees, customers should adapt to changes. It is necessary to create } \\
\text { loyal customers and improve human resources. The people who manage should } \\
\text { be professional, pay salaries in a professional manner (not only by being merely } \\
\text { sincere) and constantly strive for profit }\end{array}$ \\
\hline 4. & $\begin{array}{l}\text { Scope of Outreach } \\
\text { What amount and type of prod- } \\
\text { ucts do BMT/Kopsyah offer? }\end{array}$ & $\begin{array}{l}\text { The institution is mainly focussed on savings and financing, management of } \\
\text { zakat, infaq, and sadaqah, collaborating with bulog, retail, bank (BPR) and } \\
\text { Islamic banking }\end{array}$ \\
\hline F. & $\begin{array}{l}\text { Financial and social efficiencies } \\
\text { How can they maintain financial } \\
\text { and social efficiencies? }\end{array}$ & $\begin{array}{l}\text { Financial and social performance should be efficient in terms of the size and cal- } \\
\text { culations; the HR should be more productive. The existing financial efficiency is } \\
\text { socially beneficial for members even though it is not yet optimal. Thanks to the } \\
\text { funds for supporting and developing the poor community, people see the benefits } \\
\text { of the Islamic cooperative and are willing to participate }\end{array}$ \\
\hline
\end{tabular}

Source: Interview results (analysed), 2019.

West Java region, Indonesia after being validated by the management, members, supervisors and government elements. The results are shown in Table 1 below.

The data show that such indicators as the number of assets, deposit funds and the number of members have an upward trend. In contrast, funding, income and the number of employees decreased in 2018, even though they had been successively increasing before. Profits slightly decreased in 2016 and subsequently strengthened again.

Additionally, preliminary qualitative surveys were conducted through interviews with 14 managers. Summaries of questions and answers were recorded, written in transcript form and presented in Table 2.

There are differences in the results presented in Table 1 and Table 2, especially regarding prof- its and the number of members who show a downward trend in Table 1, while the interview results demonstrate improved efficiency.

Ideally, financial and social efficiencies can be balanced, so they can accelerate the growth of assets and significantly improve the quality of life for the surrounding community. Examination of the aspects or factors of social outreach that influence the efficiencies can help implement the balance. On the other hand, the scope of outreach regarding social efficiency has not been determined. The results of previous studies have shown differences in the relationship between financial and social efficiencies. [10] stated that social and economic efficiency have a positive correlation. Meanwhile, [11] demonstrated some results that are negatively correlated.

Based on the above discussion, it is interesting to study the effect of social outreach factors 
on efficiency. Some outreach factors that determine it are directed to the lives of people on low incomes and the poorest people. This study uses a poverty approach $[12,13]$. In addition, we test the relationship between financial and social efficiencies.

\section{Theoretical Background}

Microfinance provides low-income clients with access to basic financial services, such as loans, savings accounts, money transfer services and insurance, and assists people of various levels of poverty $[14,15]$. Due to differences in customer groups, Microfinance Institutions are deemed necessary to provide various financial products and programmes to meet people's needs.

It is possible to distinguish the depth of outreach and breadth of outreach. Due to the rapid growth of microcredit, the coverage is expanding both at the industry level and at the individual MFI level. The depth of outreach concerns the poverty level of clients of microfinance institutions. Affordability is measured by two dimensions: the depth dimension (how poor are the members) and the breadth dimension (how many people an MFI can reach). Type, age, financial independence, extent of outreach, competition, gender, and methods are the factors influencing the depth of outreach; they are represented by a loan size. Gross loan portfolio, the scale of operating, and risk significantly influence financial efficiency in Microfinance Institutions [16, 17]. This is unlike the view of [1] who suggested that outreach has a negative effect on social efficiency of Microfinance Institutions. The number of borrowers (the breadth of outreach) can improve financial sustainability in microfinance institutions. This range is measured by the breadth of the number of clients served and the volume of services including total savings in deposits and unfinished portfolio totals.

The length of outreach is a financial performance indicator that includes a return on equity, profit margin or asset return, in addition to indicators suggesting the sustainability of institutions such as operational self-sufficiency, number of years of operation, average annual changes in equity and others. The scope of outreach manages the number of clients that can be served by MFIs. An increase in recipients of funding shows that contributions to society are expanding. [18] reported that total savings in deposits and portfolio are a form of service product to the number of clients and service volume. Micro-finance institutions can facilitate people who cannot be served due to limited access to banking. [19] explain that the effectiveness of women's support and efficiency in welfare have a significant positive relationship. In contrast, the high percentage of female borrowers does not positively correlate with high levels of inefficiency [20].

[12] states that the time period for providing loans or products and services by microfinance institutions is called an outreach period, concerning the welfare of the poor in the present and the future. Financial efficiency can measure institutions' sustainability [21]. This is related to how long a MFI can allocate loans and calculate profits based on its ability to provide services to the micro business community. According to [10], the age and scale variables have less influence on efficiency. In contrast, return on equity continues to have a large impact on social efficiency [16].

[13] states that the scope of outreach is the amount of various types of loans, savings, insurance, and other products offered divided into product lines or product types. Savings and cost per borrower support the scope and scale of the economy [22]. The cost per borrower indicates that Microfinance Institutions always make efficiency improvements. [23] state that deposits do not affect financial sustainability. [24] refers to the prediction of the cost function presenting the input variable in the form of cost of funds, the output variable in the form of financing, and the environmental variable in the form of capital variable significant to total costs. The effort to collect and distribute zakat, infaq, and shadaqah is a real BMT's activity to obtain social benefits.

Financial efficiency shows how close the MFI's actual costs of fund lending activities are to the operating costs at their best level of performance, including allocating inputs such as staff, assets and subsidies, to produce the maximum output such as the amount of credit, financial adequacy or profitability, and poverty outreach. Social efficiency indicates the benefits received by members from the existence of the institution, the costs incurred to provide social benefits and an inward impact. $[19,25]$ reported that there is a positive but not significant correlation between social and financial efficiencies. [10] stated that the basis for measuring the indicators of microfinance institutions can be considered in terms of financial and social efficiencies. In addition to that, there are positive relationships in the organisations that favour the poor. [26] in his research in the Nairobi region, Kenya, proved that increased number of branches, the average number of active clients and a high percentage of female clients have made it possible to achieve greater outreach. Other factors that have a significant positive effect on outreach 
Table 3

Operationalisation of Variables

\begin{tabular}{|c|c|c|c|c|}
\hline No. & Types of Variables & Indicator (Proxy) & Measurement & Scale \\
\hline 1. & Depth of Outreach & Average Loan Instalment & Credit amount / Period of time & Ratio \\
\hline 2. & $\begin{array}{l}\text { Breadth of } \\
\text { Outreach }\end{array}$ & $\begin{array}{l}\text { Number of offices and } \\
\text { branches }\end{array}$ & $\begin{array}{l}\text { Number of offices and branches that can be accessed } \\
\text { by clients }\end{array}$ & Ratio \\
\hline \multirow{2}{*}{3.} & \multirow{2}{*}{$\begin{array}{l}\text { Length of } \\
\text { Outreach }\end{array}$} & Age & Years operating & Ratio \\
\hline & & Profit orientation & Revenue - Cost & Ratio \\
\hline \multirow{3}{*}{4.} & \multirow{3}{*}{ Scope of Outreach } & Fund collection & The sum of the deposits and borrowings received & Ratio \\
\hline & & Amount and type of financing & A variety of financing options provided to clients & Ratio \\
\hline & & Amount and type of savings & Various savings instruments provided to clients & Ratio \\
\hline 5. & Cost of Outreach & Cost per borrower & Operating expense / Number of active borrowers & Ratio \\
\hline 6. & Financial Efficiency & & $\begin{array}{c}\text { Output / Input } \\
\text { Output }=\text { Revenue } \\
\text { Input }=\text { Assets }+ \text { Number of employees }+ \\
+ \text { External funding }\end{array}$ & Ratio \\
\hline 7. & Social Efficiency & & $\begin{array}{c}\text { Output } / \text { Input } \\
\text { Output }=\text { Number of clients } \\
\text { Input }=\text { Assets }+ \text { Number of employees }+ \\
+ \text { External funding }\end{array}$ & Ratio \\
\hline
\end{tabular}

Source: Literature survey, 2019.

include the average loan instalment, volume of borrowers, return on equity and prospective customers [27]. For this reason, social outreach and economic performance have a strong positive relationship with direction.

\section{Research Method}

This study uses a mixed methodology combining quantitative and qualitative methods. The reason for that is that it is impossible to examine the stated problem and goals using only one approach [28]. Quantitative data were collected based on BMT and Islamic Cooperative financial statements that have been approved at the Annual Member Meeting (RAT). We applied purposive sampling: a sample was drawn in a certain number of the issuer's population using certain considerations or criteria [29]. There are 124 samples representing 40 Islamic Microfinance Institutions in the West Java region during the period of 2015-2018. Furthermore, we conducted indepth interviews and surveys to obtain qualitative data to clarify or deepen the existing information. 25 informants who had competencies and expertise in their fields were involved in interviews, including Deputy of the Ministry of Cooperatives and MSMEs, Provincial Cooperative Services, Chair of Gakopsyah, Chairperson of Majelis Ulama Indonesia (MUI) Economic Affairs in Bandung, supervisory board, heads/managers, administrators, academics, and other experts.

Explanation of the operationalisation of each variable (or their proxies), measurements and scales is given in Table 3 .
Data processing begins with descriptive analysis in the form of average, minimum, maximum and standard deviation. The next step is to calculate the percentage of financial and social efficiency, both of which function as the dependent variables. Efficiency is a measure of success that is assessed in terms of the size of the source/cost to achieve the results of activities [30]. A popular assessment method for measuring efficiency criteria is data envelopment analysis (DEA), which has inputs and outputs. Input variables for both efficiencies are assets, number of employees and external funding. The output variable for financial efficiency is revenue, while social efficiency is represented by the number of clients. The next step is a multivariate analysis, which is the panel data regression estimation technique. The data structure is used as a regression parameter by combining cross sectional data with the ordinary least squares method and time series. The equation model is as follows:

$$
\begin{aligned}
F E= & \beta_{0}+\beta_{1} A L I+\beta_{2} N O B+\beta_{3} A G E+\beta_{4} P O+ \\
& +\beta_{5} F C+\beta_{6} A T F+\beta_{7} A T S+\beta_{8} C P B+\varepsilon . \\
S E= & \beta_{0}+\beta_{1} A L I+\beta_{2} N O B+\beta_{3} A G E+\beta_{4} P O+ \\
& +\beta_{5} F C+\beta_{6} A T F+\beta_{7} A T S+\beta_{8} C P B+\varepsilon .
\end{aligned}
$$

The independent variables in this study consisted of average loan instalment $(A L I)$, number of offices and branches $(N O B)$, age $(A G E)$, profit orientation $(P O)$, fund collection $(F C)$, amount and type of financing $(A T F)$, amount and type of savings (ATS) and cost per borrower $(C P B)$. The dependent variable consists of financial efficiency 
$(F E)$ and social efficiency $(S E) . \beta_{0}$ is the constant value, $\beta_{1}-\beta_{8}$ are the coefficient of each variable and $\varepsilon$ is the error. Before the analysis, the data should pass the classic assumption test consisting of normality, multicollinearity, heteroscedasticity, and autocorrelation tests. Besides, a goodness of fit is needed for statistics, such as the $t$-test, the $F$-test, and the coefficient of determination.

According to [31], normality test is used to determine whether there is a disturbance or residual in the regression model that affects the normal distribution. The desired test is the absence of heteroscedasticity or homoscedasticity. All independent variables are called regardless of the multicollinearity conditions if the test results are below 0.8. According to [31], the multicollinearity test aims to examine whether the regression model has a correlation between independent variables. The correlation between independent variables will determine the results of the regression model that is built to ensure that this multicollinearity testing can be done. Multicollinearity of parameters is checked by comparing the variance inflation factor (VIF) of each independent variable. If the VIF value $<10$, it can be concluded that the data is free from the symptoms of multicollinearity. If a correlation occurs, then there is a problem called autocorrelation [32]. A good regression equation does not have an autocorrelation problem. According to the researcher, for determining whether there is a problem with autocorrelation it is necessary to use the Durbin - Watson $(D W)$ test, the provisions if $-2 \leq D W \leq+2$.

The coefficient of the independent variable and its effect on the dependent variable can be tested individually or partially using the $t$-test. The method compares each coefficient of the results obtained from the $t$-value of the independent variable with a table value through the choice of a confidence level of $1 \%, 5 \%$, or $10 \%$. The $F$-test simultaneously analyses whether there is a relationship between the set of independent variables and the dependent variables. If the calculated $F$-value is greater than $F$-table, it can be said that all independent variables together influence the dependent variables [33]. The probability value of the used independent variables is usually with a significance level of $\alpha=5 \%$. The proportion or percentage used to determine the ability of the model to explain or allow the relationship between the independent variable and the dependent variable is called the coefficient of determination. If there are more than two independent variables, then $R^{2}$ is chosen.

Data collection, reduction, presentation and conclusion as a stage of qualitative analysis must be passed in order to obtain accurate results. A summary of in-depth interviews with practitioners, government and academics is the stage of collecting data from informants. The process of sequence coding and data processing includes the steps of preparing raw data into verbatim, compressing the facts and interpretations, gathering similar facts, determining categorisation, constructing concepts and narrating.

\section{Discussion}

\subsection{Descriptive Statistics}

Descriptive statistics of each proxy variable are explained in Table 4.

The proxy variables such as age, amount and type of financing, amount and type of savings, financial efficiency and social efficiency are relatively good compared to the average loan instalment, number of offices and branches, profit orientation, fund collection and cost per borrower which have a standard deviation higher than the average value, requiring improvement.

\subsection{Efficiency Analysis}

The output of MaxDEA 7 software allows visualising the achievement of efficiency values in each BMT / Kopsyah and provides information on the original value, projected value, proportionate (radial) movement and slack movement shown in Table 5 and Table 6.

The institution is inefficient in terms of total assets input, number of employees and external funding due to the difference between the original and projected values. In contrast, the revenue output has a very small difference (proportionate movement of zero) between its projected value and the original value; it is marked $(+)$ on the slack movement, meaning that the original value of income can be increased again through the addition of inputs of Rp. 363,936.00. It is necessary to maintain the stability of internal business processes so that revenue does not decline.

Similar to financial efficiency, this institution also experienced inefficiency in total assets input, number of employees and external funding. However, the output of the number of clients has a very small difference (proportionate movement of zero) between projected value (2,760 customers) and original value (2,750 customers); it is marked (+) on the slack movement. This fact means that the original value of the number of clients can be increased again by adding 10 people as input. All employees must innovate continuously to maintain the loyalty of members. 
Table 4

Descriptive Statistics

\begin{tabular}{|l|c|c|c|c|c|}
\hline \multicolumn{1}{|c|}{ Variable / Proxy } & $\boldsymbol{N}$ & Minimum & Maximum & Mean & Standard Deviation \\
\hline $\begin{array}{l}\text { Average Loan Instalment (Hundreds of } \\
\text { Thousand Rupiahs) }\end{array}$ & 124 & 0.14912 & 24.3586 & 2.90857 & 4.11106 \\
\hline Number of Offices and Branches (Unit) & 124 & 1 & 14 & 2.072581 & 2.351866 \\
\hline Age (Years) & 124 & 1 & 39 & 11.86290 & 8.270168 \\
\hline Profit Orientation (Billions of Rupiah) & 124 & 0.002200 & 1.480043 & 0.157653 & $2.67 \mathrm{E}+08$ \\
\hline Fund Collection (Billions of Rupiah) & 124 & 0.014554 & 19.14280 & 1.692664 & 3.921789 \\
\hline Amount and Type of Financing (Unit) & 124 & 1 & 10 & 4.024194 & 2.393975 \\
\hline Amount and Type of Savings (Unit) & 124 & 1 & 13 & 5.274194 & 2.712029 \\
\hline Cost per Borrower (Thousand Rupiahs) & 124 & $7.12 \mathrm{E}-05$ & 27.81239 & 1.222753 & 4.091848 \\
\hline Financial Efficiency (\%) & 124 & 13.7607 & 100 & 77.1212 & 21.8390 \\
\hline Social Efficiency (\%) & 124 & 6.7131 & 100 & 72.2462 & 25.6785 \\
\hline
\end{tabular}

Source: Processing of EViews 9, 2019.

Table 5

Result of the Financial Efficiency Envelopment Model

\begin{tabular}{|l|c|c|c|c|}
\hline \multicolumn{1}{|c|}{ Variable } & Original Value & Projected Value & Proportionate Movement & Slack Movement \\
\hline Assets (Rupiah) & $10,584,288,502$ & $7,366,629,204$ & $-3,013,337,366$ & $-204,321,932$ \\
\hline Number of Employees (People) & 27 & 18.0824466 & -8.040135879 & -0.72419 \\
\hline External Funding (Rupiah) & $2,829,416,452$ & $1,570,589,499$ & $-849,069,300$ & $-409,757,653$ \\
\hline Revenue (Rupiah) & $2,036,022,101$ & $2,036,386,037$ & 0 & 363,936 \\
\hline
\end{tabular}

Source: MaxDEA 7 Processing results, 2019.

Table 6

Result of the Social Efficiency Envelopment Model

\begin{tabular}{|l|c|c|c|c|}
\hline \multicolumn{1}{|c|}{ Variable } & Original Value & Projected Value & Proportionate Movement & Slack Movement \\
\hline Assets (Rupiah) & $10,584,288,502$ & $5,652,468,880$ & $-4,177,620,084$ & $-754,199,538$ \\
\hline Number of Employees (People) & 27 & 18.78958729 & -7.861398548 & -0.195788355 \\
\hline External Funding (Rupiah) & $2,829,416,452$ & $1,432,125,267$ & $-894,140,985$ & $-503,150,200$ \\
\hline Number of Clients (People) & 2,750 & 2,760 & 0 & 10 \\
\hline
\end{tabular}

Source: MaxDEA 7 Processing results, 2019.

\subsection{Model and Classical Assumption Test Analysis}

In the classical assumption test, financial efficiency is the dependent variable of Model 1 and social efficiency is the dependent variable of Model 2. Panel data used in testing the model is unbalanced due to non-simultaneous observation of all individual units or missing data in individual units. Lagrange Multiplier is a test to determine whether the random effect or common effect model is the most appropriate to use.

The probability value of Breusch-Pagan (BP) of Model 1 is 0.1742 in the third column named «both». According to the hypothesis, if Prob. BP $(0.1742)>0.05$, then Ho is accepted. The probability value of Breusch-Pagan of Model 2 is 0.2772. According to the hypothesis, if Prob. BP $(0.2772)>0.05$, then $\mathrm{Ho}$ is accepted. In other words, the common effect model is the most suitable for Model 1 (Table 7) and Model 2 (Table 8).

The output of heteroscedasticity test (the Breusch-Pagan-Godfrey test) in Model 1 shows the value of the Prob. F count is 0.9908; prob- ability value $O b s^{*} R$-squared is 0.9894 . The results of Model 2 data analysis show that the Prob value. $F$ count is 0.7089 ; probability value $O b s^{*} R$ squared is 0.6925 . The values of the two models are greater than $\alpha=0.05$, meaning that the residual homoscedasticity is accepted, so there is no heteroscedasticity.

There is no multicollinearity if the value of the correlation between all tested independent variables is less than 0.8 [32]. In this study, the independent variables used were the average loan instalment, number of offices and branches, age, profit orientation, fund collection, cost per borrower, amount and type of financing, and amount and type of savings. The results of the multicollinearity test of Model 1 and Model 2 (Table 11) show that the coefficients of all variables are less than 0.8. In conclusion, the model is free from multicollinearity.

Based on the results of testing for autocorrelation using the Durbin-Watson test, the $D W$ value of equation 1 is 0.885122 and value of equation 2 is 1.012899 . The comparison of this value with 
Random Effects Test of Model 1

Lagrange Multiplier Tests for Random Effects

Null hypotheses: No effects

Alternative hypotheses: Two-sided (Breusch-Pagan) and one-sided (all others) alternatives

\begin{tabular}{|c|c|c|c|}
\hline & & st Hypothes & \\
\hline & Cross-section & Time & Both \\
\hline Breusch-Pagan & $\begin{array}{l}\text { 9.07E-05 } \\
(0.9924)\end{array}$ & $\begin{array}{l}1.846155 \\
(0.1742)\end{array}$ & $\begin{array}{l}1.846246 \\
(0.1742)\end{array}$ \\
\hline Honda & $\begin{array}{l}0.009526 \\
(0.4962)\end{array}$ & $\begin{array}{c}-1.358733 \\
--\end{array}$ & $\begin{array}{c}-0.954033 \\
--\end{array}$ \\
\hline King-Wu & $\begin{array}{l}0.009526 \\
(0.4962)\end{array}$ & $\begin{array}{c}-1.358733 \\
--\end{array}$ & $\begin{array}{c}-1.358180 \\
-\end{array}$ \\
\hline Standardized Honda & $\begin{array}{l}0.079145 \\
(0.4685)\end{array}$ & $\begin{array}{c}-1.175982 \\
-\end{array}$ & $\begin{array}{c}-48.31673 \\
-\end{array}$ \\
\hline Standardized King-Wu & $\begin{array}{l}0.079145 \\
(0.4685)\end{array}$ & $\begin{array}{c}-1.175982 \\
-\end{array}$ & $\begin{array}{c}-4.298331 \\
-\end{array}$ \\
\hline Gourierioux, et al." & - & -- & $\begin{array}{r}9.07 E-05 \\
(>=0.10)\end{array}$ \\
\hline -Mixed chi-square asym & totic critical value & & \\
\hline 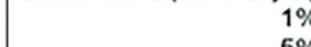 & 7.289 & & \\
\hline $\begin{array}{r}5 \% \\
10 \%\end{array}$ & $\begin{array}{r}4.321 \\
2.952\end{array}$ & & \\
\hline
\end{tabular}

Source: Data processed by EViews 9, 2019.

Random Effects Test of Model 2

Lagrange Multiplier Tests for Random Effects

Null hypotheses: No effects

Alternative hypotheses: Two-sided (Breusch-Pagan) and one-sided (all others) alternatives

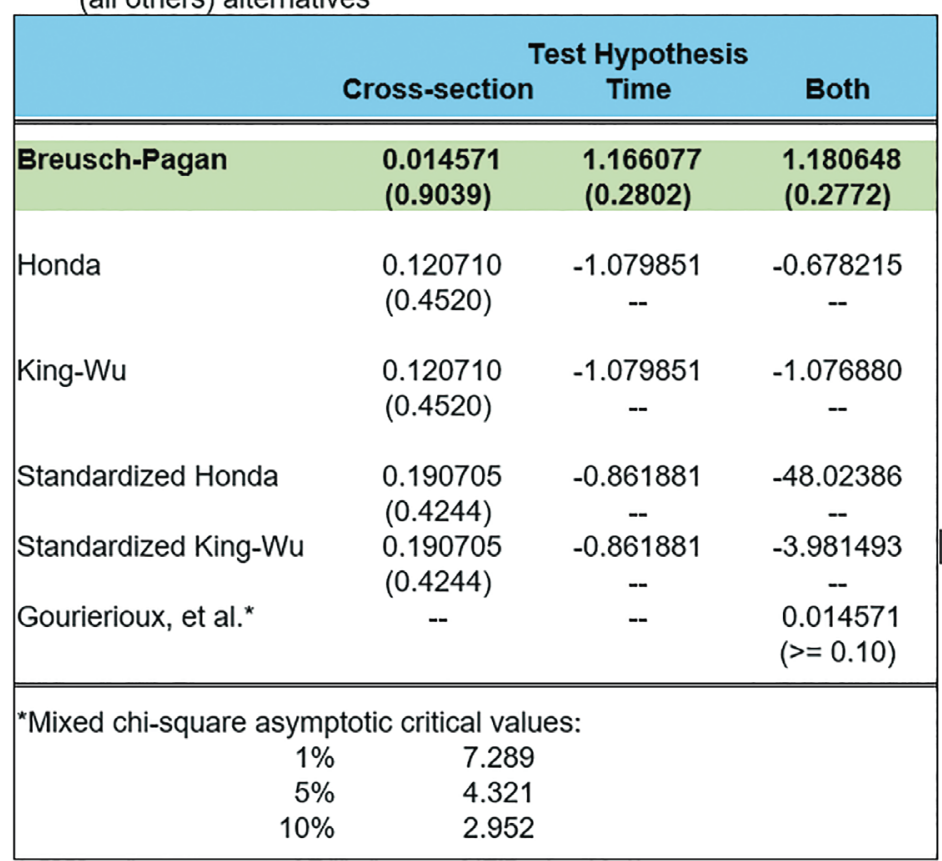

Source: Data processed by EViews 9, 2019.

Table 9

Heteroscedasticity Test of Model 1 Heteroskedasticity Test: Breusch-Pagan-Godfrey

\begin{tabular}{llll}
\hline \hline F-statistic & 0.196974 & Prob. F $(8,115)$ & 0.9908 \\
Obs ${ }^{\star}$ R-squared & 1.676146 & Prob. Chi-Square(8) & 0.9894 \\
Scaled explained SS & 2.000528 & Prob. Chi-Square(8) & 0.9810 \\
\hline \hline
\end{tabular}

Source: Data processed by EViews 9, 2019.
Heteroscedasticity Test of Model 2 Heteroskedasticity Test: Breusch-Pagan-Godfrey

\begin{tabular}{llll}
\hline \hline F-statistic & 0.679273 & Prob. F (8,115) & 0.7089 \\
Obs ${ }^{\star}$ R-squared & 5.595078 & Prob. Chi-Square(8) & 0.6925 \\
Scaled explained SS & 3.210999 & Prob. Chi-Square(8) & 0.9204 \\
\hline
\end{tabular}

Source: Data processed by EViews 9, 2019. 
Table 11

Correlation Testing Results

\begin{tabular}{|c|c|c|c|c|c|c|c|c|}
\hline & $A L I$ & NOB & $A G E$ & $P O$ & $F C$ & $A T F$ & $A T S$ & $C P B$ \\
\hline$A L I$ & 1.000000 & -0.070839 & 0.508740 & 0.501101 & 0.459327 & 0.140454 & -0.010585 & -0.117078 \\
\hline NOB & -0.070839 & 1.000000 & 0.207422 & 0.525109 & 0.292381 & 0.328914 & 0.179128 & 0.723376 \\
\hline$A G E$ & 0.508740 & 0.207422 & 1.000000 & 0.464446 & 0.524823 & 0.253534 & 0.317411 & -0.030122 \\
\hline$P O$ & 0.501101 & 0.525109 & 0.464446 & 1.000000 & 0.502305 & 0.267482 & 0.215031 & 0.419759 \\
\hline$F C$ & 0.459327 & 0.292381 & 0.524823 & 0.502305 & 1.000000 & 0.311616 & 0.183625 & 0.185874 \\
\hline$A T F$ & 0.140454 & 0.328914 & 0.253534 & 0.267482 & 0.311616 & 1.000000 & 0.529912 & 0.302490 \\
\hline$A T S$ & -0.010585 & 0.179128 & 0.317411 & 0.215031 & 0.183625 & 0.529912 & 1.000000 & 0.146226 \\
\hline$C P B$ & -0.117078 & 0.723376 & -0.030122 & 0.419759 & 0.185874 & 0.302490 & 0.146226 & 1.000000 \\
\hline
\end{tabular}

Source: Data processed by EViews 9, 2019.

the interval value of $-2 \leq D W \leq+2$ shows that the rate of this number does not result in autocorrelation. This figure is in line with previous studies explaining that the measure in determining whether there is an autocorrelation problem depends on the magnitude of the $D W$ interval.

\subsection{Multivariate Analysis}

The dependent variable of Model 1 is financial efficiency, while the dependent variable of Model 2 is social efficiency. The results of the hypotheses analysis are shown in Table 13 and Table 14 Based on the data analysis, we obtained the following multiple linear regression equations.

Analysing the output of EViews 9 software, we got the following linear regression equation:

$$
\begin{gathered}
F E=0.915809-0.016217 A L I+0.031034 N O B- \\
-0.005296 A G E-3.83 \mathrm{E}-11 P O+0.003982 F C- \\
-0.014271 A T F-0.006509 A T S-0.006442 C P B, \\
S E=0.954897-0.035739 A L I+0.025843 N O B+ \\
+0.003613 A G E-2.56 \mathrm{E}-10 P O+0.007867 F C- \\
-0.020283 A T F-0.022551 A T S+0.002269 C P B .
\end{gathered}
$$

Table 12

Autocorrelation Testing Results

\begin{tabular}{|c|c|c|}
\hline Model & Score & Decision \\
\hline Equation 1 & $\begin{array}{c}\text { Durbin - Watson } \\
0.885122\end{array}$ & No autocorrelation \\
\hline Equation 2 & $\begin{array}{c}\text { Durbin - Watson } \\
1.012899\end{array}$ & No autocorrelation \\
\hline
\end{tabular}

Source: Data processed by EViews 9, 2019.

Data analysis can be explained as follows.

a. Influence of Average Loan Instalments on Financial and Social Efficiencies

Based on statistical test results, average loan instalments are a proxy for the depth of outreach that has a significant negative effect on financial and social efficiencies. In regards to the IMFIs functions, in terms of shares or capital it is necessary to increase the participation of members' deposits rather than credits through banks or the like. The cost of funds for member savings is very small or zero compared to the costs of operating with third parties. This means that the proportion of funds used by larger banks will reduce financial efficiency. In their business activities, banks

Table 13

Result of Multivariate Analysis of Model 1

\begin{tabular}{|l|c|c|c|}
\hline \multicolumn{1}{|c|}{ Variable } & Coefficient & $\boldsymbol{t}$-Statistic & Prob. \\
\hline$C$ & 0.915809 & 19.76753 & 0.0000 \\
\hline$A L I$ & -0.016217 & -2.556572 & $0.0119^{* *}$ \\
\hline$N O B$ & 0.031034 & 2.481903 & $0.0145^{* *}$ \\
\hline$A G E$ & -0.005296 & -1.796213 & $0.0751^{* * *}$ \\
\hline$P O$ & $-3.83 \mathrm{E}-11$ & -0.368608 & 0.7131 \\
\hline$F C$ & 0.003982 & 0.695427 & 0.4882 \\
\hline$A T F$ & -0.014271 & -1.538678 & 0.1266 \\
\hline$A T S$ & -0.006509 & -0.801755 & 0.4243 \\
\hline$C P B$ & -0.006442 & -0.977057 & 0.3306 \\
\hline$R$-squared & 0.281273 & $F$-statistic & 5.625636 \\
\hline Adjusted $R$-squared & 0.231274 & Prob $(F$-statistic $)$ & 0.000005 \\
\hline Durbin - Watson stat & 0.885122 & & \\
\hline
\end{tabular}

Source: Data processed by EViews 9, 2019.

Note: ${ }^{*}=p<0.01 ;{ }^{* *}=p<0.05 ;{ }^{* * *}=p<0.1$. 
Result of Multivariate Analysis of Model 2

\begin{tabular}{|l|c|c|c|}
\hline \multicolumn{1}{|c|}{ Variable } & Coefficient & $\boldsymbol{t}$-Statistic & Prob. \\
\hline$C$ & 0.954897 & 22.48877 & 0.0000 \\
\hline$A L I$ & -0.035739 & -6.147285 & $0.0000^{*}$ \\
\hline$N O B$ & 0.025843 & 2.255058 & $0.0260^{* *}$ \\
\hline$A G E$ & 0.003613 & 1.337183 & 0.1838 \\
\hline$P O$ & $-2.56 \mathrm{E}-10$ & -2.696610 & $0.0081^{*}$ \\
\hline$F C$ & 0.007867 & 1.498895 & $0.0187^{* *}$ \\
\hline$A T F$ & -0.020283 & -2.386220 & $0.0030^{*}$ \\
\hline$A T S$ & -0.022551 & -3.030775 & 0.7080 \\
\hline$C P B$ & 0.002269 & 0.375510 & 18.54373 \\
\hline$R$-squared & 0.563318 & $F$-statistic & 0.000000 \\
\hline Adjusted $R$-squared & 0.532941 & Prob $(F$-statistic $)$ & \\
\hline Durbin - Watson stat & 1.012899 & & \\
\hline
\end{tabular}

Source: Data processed by EViews 9, 2019.

Note: ${ }^{*}=p<0.01 ;{ }^{* *}=p<0.05 ;{ }^{* * *}=p<0.1$.

should not only pursue profitability, but also develop activities to reduce poverty.

This statement is in line with the qualitative findings in the form of interviews and reports of Annual Member Meetings. While the average loan instalment of members varies depending on their respective economic capabilities, the ultimate goal is to ensure the welfare of the poor and financial increase. The process of empowering the poor begins with donations taken from zakat, infaq, sadaqah, endowments, and grants.

This result is consistent with the empirical findings of [1] confirming the existence of a negative correlation between efficiency and outreach. The high transaction costs of providing microcredit make it inefficient and threaten the financial sustainability of MFI. The results of this study are supported by [34] stating that the variables of age, regulatory status, loans per loan officer, assets that have a significant influence on social performance, while the profit status has no such influence. This means that the average loan and small instalments as a proxy for the depth of outreach will greatly contribute to the poor and poorest communities.

b. Influence of the Number of Offices and Branches on Financial and Social Efficiencies

The number of offices and branches in Islamic microfinance as a proxy for the breadth of reach has a high influence on financial and social efficiency. Through the opening of offices and branches, BMT / Kopsyah can reach remote areas or regions. This factor is considered effective and efficient because it allows keeping in touch with members and prospective members. BMT is still adjusting the use of high technology, such as JIT, fintech mobile, 24-hour transactions, and others in contrast to financial institutions such as banks that rely more on high technology (high tech). What remains to be considered is an increase in the financing portfolio of new customers, not just opening of branches. Financial efficiency is directly proportional to the level of productivity and member growth.

This strategy also increases the number of beneficiaries and services. Usually they include member-training packages, cheap food, ambulance services and others. The increase in the number of branches can be efficient if followed by the provision of various services and activation of members to increase propaganda and revenue or profit. Therefore, the social efficiency must increase. In other words, financial and social efficiency can be achieved if the total number of borrowers increases through business expansion, portfolio addition, financing, project work in various sectors.

In his research, [26] takes a sample of 30 MFIs in Kenya explaining that the increasing number of branches, the average number of active clients and a high percentage of female clients have enabled achieving greater reach and can build sustainability.

\section{c. Influence of Age on Financial and Social Efficiencies}

The age variable (from establishing an operation to achieving sustainability) of Islamic Microfinance Institutions as a proxy for the length of outreach has a high negative effect on financial efficiency but does not significantly affect social efficiency. The longer BMT/Kopsyah runs its activities, the more financial and socio-economic efficiencies of the institution decrease. Overall, the performance of managers has decreased several times in achieving the targets set by the BMT/ Kopsyah and continued to decrease. 
The interviews results and observations in the field prove that the increase in age is good as long as a manager is trustworthy. If it is not good, then there must be something wrong. There are also different opinions that the institution is not necessarily good with age, depending on whether the members and employees' turnover is high or low. The high turnover rate will have an inefficient effect, as it affects the funds raised. Increasing age should increase business volume and number of members. In case of linear development of the age and volume of the business, it is possible to programme various social activities, such as free ambulance, joint study, toilet repair, disaster management and others.

This result is in line with the empirical research of [10] stating that the oldest microfinance institutions are proportionally less efficient (economically and socially) compared to the young ones. In this sector, the length of work period is not an important measure for efficient employment. In contrast, age can negatively influence efficiency.

d. The Influence of Profit Orientation on Financial and Social Efficiencies

The profit orientation in Islamic business activities as a proxy for the length of outreach does not significantly affect financial efficiency but has a negative significant effect on social efficiencies. IMFIs that rely on funding the poor are limited in increasing the average financing of their members. This limitation includes innovations in adding new savings and financing products. The increase in profit is not significant because the obtained revenue is also not large. Income is more dependent on loan services (al qard) or administrative income only. It still needs to be improved in terms of financial efficiency, but assets grow faster.

IMFIs integrate the social principles of Islam concerning the poorest groups of people through microfinance providing access and financial services to these groups. However, they contrast with institutions that receive high profits due to utilising external funding and increasing member shares as BMT/Kopsyah capital.

\section{e. Influence of Fund Collection on Financial and Social Efficiencies}

The fund collection as an effort to enlarge Islamic financial business activities and a proxy of the scope of outreach has an insignificant effect on financial and social efficiencies. In this study, the fund collection focussed on principal savings, members' mandatory savings, and grant funds. It is proven that third party funds are still an option to fulfil members' requests in terms of loans and financing. When funds are insufficient for financ- ing, external funding is needed to establish partnerships with banks, non-banks (micro-capital), and productive endowments.

The interviews revealed that Islamic microfinance institutions sought to implement a shared economic system as fairly as possible. The basic principles of Islamic finance were also implemented: the name of Allah and his messenger as the basis, fairness, freedom from exploitation, profit and loss sharing, the lawfulness of business, prohibition of speculative behaviour, consideration of the level of return and risk, and help to weaker communities (ta'awun).

This observation is similar to the empirical study conducted by [23], which states that the coefficient of deposits is positive, but does not have a high effect on financial sustainability. That study was conducted at 29 MFIs during the period 20082012 in Bangladesh with 145 observations using the data panel. The research results are not in line with the study of [16], which reports that the return on assets (ROA) or profitability has a negative but not significant effect on efficiency. This statement is also in contrast to the findings of [21], which reveal that profit orientation has a significant positive impact on financial efficiency.

\section{$f$. Influence of Amount and Type of Financing} on Financial and Social Efficiencies

The amount and type of financing (some of the products of Islamic Microfinance Institutions) as a proxy of the scope of outreach have a small contribution for financial efficiency. However, they have a significant negative effect on social efficiency. The increasing number and variety of types of BMT/Kopsyah financing products can decrease financial efficiency even though there is no significant effect. The financing business is directed at the financing of macro, small, and low-level businesses. The forms of financing include mudharabah, musyarakah, murabahah, al-qardhul hasan, and others.

The analysis is in line with the results of the interview stating that Kopsyah products only focus on deposits and loans, but not on others. While the scope of BMT is in the form of financing and deposits, it can be modified into a Multipurpose Cooperative, where the products are more varied. There is no guarantee that the number of products that are slightly inefficient and have many variations will be more efficient, as promotional and other costs are difficult to replace. Diversification will be efficient if adjusted to the needs and desires of members; in this case, they will not switch to other financial institutions.

These results correlate with the findings of [35] who suggested that indicators of the scope of out- 
reach include variations in products or services differing in the number and types of the offered savings and non-financial products. Meanwhile, [13] stated that various types of loans, savings, insurance and other products offered are divided based on product lines or types of products. This means that the aspects of the scope of outreach relate to the number of types of financing offered by BMTs to the community, so people can choose them to improve their economic well-being in accordance with Islamic companies.

\section{g. Influence of Amount and Type of Savings on Financial and Social Efficiencies}

The amount and type of savings as the main product of BMT/Kopsyah and a proxy of the scope of outreach have a low impact on financial efficiency but have a high negative effect on social efficiency. It is necessary to pay attention to the members' saving behaviour that is related to the increase in BMT/Kopsyah assets. An increase in savings funds means an increase in assets owned. Due to high assets, the range of services to the community will be even wider, meaning that the community will benefit more. Therefore, the willingness of members to save funds needs to be taken seriously. The Islamic savings product are characterised by specific attributes and elements, including non-involvement of the community, the use of a profit sharing system and avoidance of gharar and masyir.

The interview results state that Kopsyah products only focus on savings and loans, while BMT can modify it and add other variations. Deposit products include zakat, infak, sadaqah, tamwil, ordinary savings (daily), long-term deposits, hajj savings, qurban savings, money for marriage, and other savings. While shops serve street vendor customers, they are accustomed to saving first. Simultaneously, the middle and upper-middle economies are advised to save on a daily, weekly, and monthly basis. MFIs should be one-stop services, financial services that provide whatever members need so they can receive benefits when joining. Revenue sharing is not the main purpose of the transaction to save funds; rather, it provides safe, non-queued and socially oriented services.

[23] state that deposits do not affect financial sustainability, meaning that the research results agree with previous studies. Product attributes and service quality of Islamic savings have a positive effect on members' willingness to save funds in BMT. If the community believes that a savings product complies with Islamic provisions and serves the community (members), then the community will not transfer the saved funds to other financial institutions.

\section{h. The Influence of Cost per Borrower on Financial and Social Efficiencies}

The cost per borrower of Islamic Microfinance Institutions as a proxy for the costs of outreach does not have a significant effect on financial and social efficiencies. IMFIs, which only rely on fund collection of their members, focus on al-qard and administration/infak/sadaqah services. Covered operating costs are also very small, limited to employee incentives, RATs, zakat, administration, and other small operating costs. According to the experience of Islamic microfinance institutions, transaction costs of serving the poor are relatively high because of the very small size of each financial transaction. This situation may change due to cooperation with banks or other donor institutions, and various income components such as revenue sharing, margin, financing services, bank yields/services, administration, business, and other operating income.

The results of interviews and observations of IMFIs activities explained that operating costs are inefficient if the economies of scale are small or under Rp. 1 billion. Savings are a necessity, thus, it is important to prioritise the activities and their funding. There has to be an increase in member deposits in the form of principal, mandatory, and special savings. IMFIs should also look for loans and unused funds in People's Credit Banks (BPR) or Islamic banks. Capital adequacy will increase the trust of borrowers and savers because IMFIs are capable of providing funds to people if they suffer losses or want to expand their business [36]. The results of studies indicating that operating costs are directly proportional to financial efficiency do not support some previous findings.

\subsection{Goodness of Fit Analysis}

The average loan instalments, number of offices and branches, age, profit orientation, fund collection, amount and type of financing, amount and type of savings and cost per borrower simultaneously have a significant effect on financial and social efficiencies.

The determination coefficient test (R2) indicates how the model explains the variation in the dependent variable. If there is more than one independent variable, it is recommended to use the adjusted R-squared value when assessing the best regression model [31]. The test results of the first model show the adjusted R2 value of 0.231274 meaning that $23.1274 \%$ of the variation in the dependent variable of financial efficiency can be explained by eight variations of the independent variables. The remaining $76.8726 \%$ is explained by other variables outside the study. Meanwhile, 
after testing the second model, we obtained an adjusted R2 value of 0.532941 , meaning that $53.2941 \%$ of the variation in the dependent variable of social efficiency can be explained by eight variations of the independent variables. The remaining $46.7059 \%$ is explained by other variables outside the study. According to [37], the standard coefficient of determination is divided into very low, low, medium, strong, and very strong categories. Compared to existing standards, the obtained results are included in the strong category.

\section{Conclusion}

Financial and social efficiencies in general can be considered as moderate and high efficiency; they can be optimised by using total asset, the number of employees and external funding as input variables as well as income and the number of borrowers as output variables. This model explains that financial and social efficiencies of Islamic Microfinance Institutions are built comprehensively based on proxies for breadth, depth, length and scope of outreach. These factors should be considered carefully in order to obtain the desired conditions for the survival of the institution.

The order of consistency and contribution in determining financial and social efficiency comes from the number of offices and branches, average loan instalments, age of the institution, profit orientation, amount and types of financing and amount and type of savings. The number of offices and branches is the only variable that contributes positively and according to expectations, meaning that it is possible to deliver high-touch service to customers due to the proximity of institutions in the wider region. A trade-off between the need for the breadth of outreach for the poor with other variables had a negative impact on BMT / Kopsyah.

The amount and type of financing and savings have significant negative impact on social efficiency, disproving the argument that BMT should have several business products and not just one. This result is supported by the statement that there are no guarantees that product diversification will improve financial or social efficiency. The offered product is useless if it does not influence the end user. The cost per borrower as a proxy for costs of outreach does not have a high effect on financial and social efficiencies. Transaction costs of serving the poor are relatively high because of the very small size of each financial transaction. Due to the dual mission of MFIs that function commercially and socially, both efficiencies are mutually reinforcing. The contribution that is realized in the coefficient of determination is $23.1274 \%$ and $53.2941 \%$. In the future, the research wll be continued by classifying IMFIs according to the size of each asset and increasing the number of observations to obtain more comprehensive results.

\section{References}

1. Hermes, N., Lensink, R. \& Meesters, A. (2011). Outreach and Efficiency of Microfinance Institutions. SOM Research Reports: Vol. 08002. Groningen: University of Groningen, SOM Research School, 29.

2. Charitonenko, S. \& Fernando, N. A. (2004). Commercialization of Microfinance: Perspectives from South and Southeast Asia. ADB: 90.

3. Conning, J. (1999). Outreach, Sustainability and Leverage in Monitored and Peer-Monitored Lending. Journal of Development Economics, 60(1), 51-77. DOI: https://doi.org/10.1016/S0304-3878(99)00036-X.

4. Kereta, B. B. (2007). Outreach and Financial Performance Analysis of Microfinance Institutions in Ethiopia. In: African Economic Conference United Nations Conference Center (UNCC), Addis Ababa, Ethiopia 15-17 November 2007 (pp. 1-31). UNCC.

5. Nugroho, A. (2009). The Commercialization-Outreach Nexus of Microfinance in Indonesia: The Case Study of Microfinance Industry in Boyolali, Central Java. Jurnal Ekonomi dan Pembangunan, 17(2), 55-64.

6. Acharya, P. \& Acharya, U. (2006). Sustainability of Microfinance Institution from Small Farmers' Perspective: a Case of Rural Nepal. International Review of Business Research Papers, 117-126.

7. Ghalib, A. K. (2011). Estimating the Depth of Microfinance Programme Outreach: Empirical Findings from Rural Pakistan. The University of Manchester: Brooks World Poverty Institute, 34.

8. Montgomery, H. \& Weiss, J. (2011). Can Commercially-Oriented Microfinance Help Meet the Millenium Development Goals? Evidence from Pakistan.World Development. The University of Bradford Institutional Repository, 39(1), 87-109.

9. Hartarska, V., Shen, X. \& Mersland, R. (2013). Scale Economies and Input Price Elasticities in Microfinance Institutions. Journal of Banking and Finance, 37 (1), 118-131. DOI: https://doi.org/10.1016/j.jbankfin.2012.08.004.

10. Gutierrez-Goiria, J., San-Jose, L. \& Retolaza, J. L. (2016). Social Efficiency in Microfinance Institutions: Identifying How to Improve It. Journal of International Development, 29(2), 259-280. DOI: 10.1002/jid.3239.

11. Pava, M. L., \& Krausz, J. (1996). The Association Between Performance: The Paradox Corporate and Financial of Social Cost. Journal of Business Ethics, 15(3), 321-357.

12. Schreiner, M. (1999). Aspects of Outreach: A Framework for Discussion of the Social Benefits of Microfinance. International Development, 14(5(99)), 591-603. 
13. Rao, K. R. M. \& Fitamo, T. L. (2015). Concepts And Measures of Outreach and Sustainability in Microfinance Institutions : A Comprehensive Literature Review. Research Journal of Finance and Accounting, 6(21), 41-49.

14. Ledgerwood, J. (2000). Microfinance Handbook: An Institutional and Financial Perspective. Washington, D.C.: The World Bank, 286.

15. Robinson, M. S. (2001). The Microfinance Revolution, Volume 1: Sustainable Finance for the Poor. Washington, D.C.: The World Bank, 304.

16. Kar, S. \& Deb, J. (2017). Efficiency Determinants of Microfinance Institutions in India: Two Stage DEA Analysis. Central European Review of Economics and Management, 1(4), 87-115.

17. Roy, P. (2017). Unearthing the Double Bottom Line Commitments of Indian Microfinance Institutions. IRAInternational Journal of Management \& Social Sciences, 9(1), 14-26. DOI: https://doi.org/10.21013/jmss.v9.v1.p3.

18. Yaron, J. (1994). What makes rural finance institutions successful? World Bank Research Observer, 9(1), 49-70. DOI: https://doi.org/10.1093/wbro/9.1.49.

19. Gutiérrez-Goiria, Serrano-Cinca, C. \& Molinero, C. M. (2007). Social Efficiency in Microfinance Institutions. Journal of the Operational Research Society, 60(1), 104-119. DOI: https://doi.org/10.1002/jid.3239.

20. Nilsholm, N. \& Heidmann, S. (2012). Compatibility between Outreach and Efficiency in the Microfinance Market. School of Economics and Management, Lund University, 37.

21. Widiarto, I. \& Emrouznejad, A. (2015). Social and financial efficiency of Islamic microfinance institutions: A Data Envelopment Analysis application. Socio-Economic Planning Sciences, 50, 1-17. DOI: https://doi.org/10.1016/j. seps.2014.12.001.

22. Oteng-Abayie, E. F., Amanor, K. \& Frimponng, J. M. (2011). The measurement and determinants of economic efficiency of microfinance institutions in Ghana : a Stochastic Frontier approach. African Review of Economics and Finance, 2(2), 149-166.

23. Hossain, M. S. \& Khan, M. A. (2016). Financial Sustainability of Microfinance Institutions ( MFIs ) of Bangladesh. European Journal of Business and Management, 6(6), 69-78.

24. Mulyaningsih, Y., Nuryantono, N., Oktaviani, R., Firdausy, C. M. (2016). Trade-off Between Financial Sustainability and Outreach of Islamic Microfinance in Rural. Kajian dan Ekonomi Keuangan, 20(1), 44-60. Retrieved from: http://fiskal. depkeu.go.id/ejournal (Date of access: 04.02.2020) (In Ind.)

25. Gutiérrez-Goiria, J. \& Goitisolo Lezama, B. (2011). Profitability and Social Performance of Microfinance Institutions: Empirical Evidence of Relations between Different Types of Variables. Revista Deconomia Mundal, 27, 189-214.

26. Arodi, J. O. (2013). The Relationship between Outreach and Financial Sustainability of Microfinance Institutions in Nairobi County. Department of Finance and Accounting, School of Business, University of Nairobi, 60.

27. Karanja, A. M. (2014). Relationship Between Outreach and Financial Performance of Deposit Taking Microfinance Institutions in Kenya. International Journal of Academic Research in Accounting, Finance and Management Sciences, 2, $176-$ 184.

28. Creswell, J. (2013). Qualitative Inquiry and Research Design: Choosing among Five Approaches (3rd ed.). Thousand Oaks, CA: SAGE. 414.

29. Sugiyono. (1999). Metode Penelitian Bisnis (6th ed.) [Business Research Methods (6th ed.)]. Bandung: Alfabeta. 389. (In Ind.)

30. Danfar. (2009). Pengertian Efisiensi dan Efektifitas [Definition of Efficiency and Effectiveness], 1-4. Retrieved from: http://www.dansite.wordpress.com (Date of access: 05.02.2020) (In Ind.)

31. Ghozali, I. (2011). Aplikasi Analisis Multivariate Dengan Program SPSS. [Multivariate Analysis Application with SPSS Program]. Semarang: Badan Penerbit Universitas Diponegoro, 410. (In Ind.)

32. Gujarati, D. N. (2012) Basic Econometrics. Tata McGraw-Hill Education, Noida. 1024.

33. Ghozali, I. (2006). Aplikasi Analisis Multivariate Dengan Program SPSS (4th ed.) [Multivariate Analysis Application with SPSS Program (4th ed.).]. Semarang: Badan Penerbit Universitas Diponegoro, 254. (In Ind.)

34. Churchill, S. A. \& Marr, A. (2014). Sustainability and Outreach: A Comparative Study of MFIs in South Asia and Latin America \& the Caribbean. Bulletin of Economic Research, 69(4), 19-41. DOI: https://doi.org/10.1111/boer.12100.

35. Woller, G. (2000). Reassessing The Financial Viability of Village Banking: Past Performance and Future Prospects. Microfinance Information Exchange, 5, 3-8.

36. Ledgerwood, J. (1999). Microfinance Handbook: An Institutional and Financial Perspective. Washington, D.C.: The World Bank, 304.

37. Sugiyono. (2012). Metode Penelitian Kuantitatif dan Kualitatif dan R \& D [Business research methods (quantitative, qualitative and RङD approaches)]. Bandung: Alfabeta, 464. (In Ind.)

\section{About the authors}

Purwanto - PhD in Islamic Finance, Senior Researcher, Director of Students Affair, Alumni and Counceling, Management Study Program, School of Business, President University; Scopus Author ID: 57196194532 (Jababeka Education Park, Jl. Ki Hajar Dewantara, Kota Jababeka, Bekasi, 17550, West Java, Indonesia; e-mail: purwanto@president.ac.id).

Ina Primiana - Doctor of Industrial Management Engineering, Professor, Chair of the Focus Group SME's Indonesian Association of Bachelor of Economics, Chairman of the West Java Economic Forum Expert Council, Expert Team of the 
National Defense Council, Faculty of Economics and Business at Padjadjaran University; Scopus Author ID: 55437876800 (46 A, Dipati Ukur St., Bandung 40132, West Java, Indonesia; e-mail: ina.sagir@fe.unpad.ac.id).

Dian Masyita - Doctor of Islamic Finance, Professor; Assessor of National Tertiary Accreditation Institutions for Islamic Economics, Sharia Business Management and Sharia Banking Study Programs; Reviewer of the Indonesian Ministry of Finance's Educational Fund Management Institution, Faculty of Economics and Business at Padjadjaran University; Scopus Author ID: 56820137900 (46 A, Dipati Ukur St., Bandung 40132, West Java, Indonesia; e-mail: dian.masyita@fe.unpad.ac.id).

Erie Febrian - Doctor in Islamic Bank Risk Management, Associate Professor, Deputy Director at the Doctorate School of Management \& Business, Researcher, Management Institute of the Faculty of Economics (LMFE), Faculty of Economics and Business, Padjadjaran University; Scopus Author ID: 36815840700 (46 A, Dipati Ukur St., Bandung 40132, West Java, Indonesia; e-mail: erie_febrian@fe.unpad.ac.id).

\section{Информация об авторах}

Пурванто - PhD в области исламских финансов, старший научный сотрудник, заведующий по делам студентов, выпускников и консультантов; Программа обучения менеджменту, Школа бизнеса, Президентский университет; Scopus ID: 57196194532 (Индонезия, 17550, Западная Ява, г. Бекаси, Кота Джабабека, ул. Ки Хаджар Девантора, Образовательный парк Джабабека; e-mail: purwanto@president.ac.id).

Примиана Ина - доктор в области промышленного менеджмента, профессор; председатель фокус-группы Индонезийской ассоциации бакалавров экономики МСП; председатель экспертного совета Западно-Яванского экономического форума, экспертная группа Совета национальной обороны; факультет экономики и бизнеса, Паджаджаранский университет; Scopus ID: 55437876800 (Индонезия, 40132, Западная Ява, г. Бандунг, ул. Дипати Укур, 46 A; e-mail: ina.sagir@fe.unpad.ac.id).

Масьита Дайан - доктор в области исламских финансов, профессор; оценщик национальных высших учебных заведений по исламской экономике, шариатскому управлению бизнесом и шариатским банковским программам; рецензент образовательной программы Института управления фондами Министерства финансов Индонезии; факультет экономики и бизнеса, Паджаджаранский университет; Scopus ID: 56820137900 (Индонезия, 40132, Западная Ява, г. Бандунг, ул. Дипати Укур, 46 A; e-mail: dian.masyita@fe.unpad.ac.id).

Фебриан Эри - доктор в области управления рисками исламского банка, доцент; заведующий докторантурой Школы менеджмента и бизнеса, научный сотрудник Института менеджмента экономического факультета, факультет экономики и бизнеса, Паджаджаранский университет; Scopus ID: 36815840700 (Индонезия, 40132, Западная Ява, г. Бандунг, ул. Дипати Укур, 46 A; e-mail: erie_febrian@fe.unpad.ac.id).

Дата поступления рукописи: 05.09.2019.

Прошла рецензирование: 02.03.2020. Принято решение о публикации: 15.09.2020.

Received: 05 Sep 2019. Reviewed: 02 Mar 2020. Accepted: 15 Sep 2020. 